Georgetown University Law Center

Scholarship @ GEORGETOWN LAW

1991

\title{
The Ideal of Liberty: A Comment on Michael H. v. Gerald D.
}

Robin West

Georgetown University Law Center, west@law.georgetown.edu

Georgetown Public Law and Legal Theory Research Paper No. 11-67

This paper can be downloaded free of charge from:

https://scholarship.law.georgetown.edu/facpub/650

http://ssrn.com/abstract=1846843

139 U. Pa. L. Rev. 1373 (1991)

This open-access article is brought to you by the Georgetown Law Library. Posted with permission of the author. Follow this and additional works at: https://scholarship.law.georgetown.edu/facpub

Part of the Civil Rights and Discrimination Commons, Constitutional Law Commons, Family Law Commons, Jurisprudence Commons, and the State and Local Government Law Commons 


\section{ROBIN WEST $\dagger$}

What is the meaning and content of the "liberty" protected by the due process clause of the fourteenth amendment? In Michael $H$. v. Gerald $D .{ }^{1}$ Justices Brennan and Scalia spelled out what at first blush appear to be sharply contrasting understandings of the meaning of liberty and of the substantive limits liberty imposes on state action. ${ }^{2}$ Justice Scalia argued that the "liberty" protected by a substantive interpretation of due process is only the liberty to engage in activities historically protected against state intervention by firmly entrenched societal traditions. I will sometimes call this the "traditionalist" interpretation of liberty. Justice Brennan, by contrast, argued for a much broader, and nominally more liberal, interpretation. The liberty protected by the fourteenth amendment, Brennan contended, means the liberty to enjoy those broad areas of life-such as parenthood, privacy, and sexuality-which have been identified as essential to liberty by the relevant judicial precedent of the liberal Warren and Burger Court era. I will sometimes call this the "precedential" interpretation.

In this essay I will briefly argue that, appearances notwithstanding, Justice Brennan's precedential interpretation of liberty, no less than Justice Scalia's traditionalist one, is at its root deeply conservative. I will then argue that the best explanation for the conservatism of even this nominally "liberal" interpretation of liberty by an unquestionably liberal jurist is that it stems from the general need of all members of the Court-liberal as well as conservative-to interpret the Constitution in a way that vindicates the "jurisprudential virtues" of good judicial decision-making. Those virtues, I will suggest, are themselves conservative, and perhaps necessarily so. It is therefore not surprising that constitutional interpretations rendered by even the liberal Justices-such as Justice Brennan's interpretation of "liberty" in Michael H.-have conservative overtones and consequences.

Second, I will suggest that the Justices' collective need to constrain interpretation by the ethical demands of the adjudicative.

$\dagger$ Professor, University of Maryland School of Law.

109 S. Ct. 2333 (1989).

2 See id. at 2341-46 (Scalia, J.); id. at 2349-59 (Brennan, J., dissenting). 
virtues has cramped our understanding of liberty, as well as of the Constitution's other general phrases. We ought to liberate the interpretive questions-what is liberty, and what constraints does it impose on state action-from their historical associations with the ethical need to constrain judicial decision-making. By doing so, we might achieve a more progressive, but also more accurate, understanding of the nature of individual liberty than that propounded by either Justice Brennan or Justice Scalia in their respective decisions in Michael $H$.

In his plurality opinion in Michael $H$., Justice Scalia argued, partly in a footnote in which only one member of the Court joined, ${ }^{3}$ that the "liberty" protected by substantive due process must be understood as including only the liberty to engage in activities or forms of life which have been "traditionally" protected against communal sanction, state action, or majoritarian control. ${ }^{4}$ The requisite "tradition" in this formulation, Scalia went on to argue, must be interpreted as narrowly as is sensibly possible. ${ }^{5} \mathrm{He}$ then argued that the "liberty" interest which Michael $H$. sought to enforce-the liberty of an "adulterous biological father" to maintain a relationship with his biological daughter, when the child's mother is married to another man-has not been protected by any specific, narrowly tailored, societal tradition. Therefore, Scalia concluded, the California statute establishing a conclusive presumption in favor of the paternity of the mother's husband did not unconstitutionally deny the biological father his liberty. ${ }^{6}$ Even assuming that we have traditionally protected "parenthood," Scalia argued, we have not traditionally protected the parental liberties of an adulterous father over his daughter born to a mother who is married to another man, and accordingly the statute establishing the conclusive presumption in favor of the "marital" father violates no constitutional stricture. ${ }^{7}$

Regardless of the merits of Michael $H$. itself, it seems fair to say, as Justice Brennan argued in dissent, that the interpretation of liberty and hence of substantive due process espoused by Justice Scalia in Michael $H$. is so narrow that if embraced by the Court it would lead to the effective end of the doctrine. ${ }^{8}$ The claim that

${ }^{3}$ See id. at 2344 n.6 (joined by Rehnquist, C.J.).

4 See id. at 2341-46.

5 See id. at 2344 n.6 (referring to "the most specific level at which a relevant tradition ... can be identified ${ }^{\prime \prime}$ ).

${ }^{6}$ See id. at 2341-46.

7 See id. at 2344.

${ }^{8}$ See id. at 2350-51 (Brennan, J., dissenting). 
there exists a narrow, specific tradition protecting a liberty which is threatened by a challenged statute is fatally undermined by the existence of the statute itself. Obviously, it is difficult, if not impossible, to argue that Californians have a "tradition" protecting the rights of adulterous biological fathers when they have a statute granting a conclusive presumption of paternity to the husband of the child's mother. Furthermore, Scalia's position, if accepted, would undermine not only Michael $H$. but also virtually every major substantive due process case of the last twenty years. ${ }^{9}$ For it is surely hard, if not impossible, to argue that we have a "tradition" protecting the rights of women to procure abortions, in the face of multiple statutes criminalizing abortion. It is hard to argue that we have a tradition protecting the sexual autonomy or privacy of homosexuals, in the face of sodomy laws. It is hard to argue that we have a tradition protecting the rights of patients in vegetative states to die with dignity free of technological intervention, in the face of numerous state statutes heavily qualifying that freedom. Indeed, it is hard to argue, even, that we have a tradition protecting the rights of married persons to use contraceptives in the face of statutes criminalizing their distribution. ${ }^{10}$ If Scalia is right to insist that the content of the "liberty" that limits the substantive scope of the police power must come from societal traditions, and right to insist that those traditions must be narrowly construed, then it seems fair to conclude that there is, in practical effect, no such limit. The police power of the states is substantively limited only by other express constitutional provisions, not by the content of the "liberty" guaranteed against invasion without "due process" in the fourteenth amendment.

At least at first blush, Justice Brennan's understanding of due process and the liberty it protects, spelled out in his dissenting opinion in Michael $H_{\text {., }}{ }^{11}$ sharply contrasts with, and is considerably

${ }^{9}$ On this ground, Justice O'Connor objected to Scalia's formulation of due process clause analysis. She thus refused to concur in the footnote in which he made

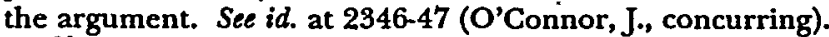

10 Under Scalia's test, the following cases all seem incorrectly decided: Cruzan v. Director, Mo. Dep't of Health, 110 S. Ct. 2841 (1990) (upholding right to die); Roe v. Wade, 410 U.S. 113 (1973) (upholding right to an abortion); Griswold v. Connecticut, 381 U.S. 479 (1965) (upholding right of married persons to use contraception); Eisenstadt v. Baird, 405 U.S. 498 (1972) (upholding right of unmarried individuals to use contraception). On the other hand, his test seems consistent with the decision in Bowers $v$ Hardwick, 478 U.S. 186 (1986) (denying right to engage in consensual sodomy).

11109 S. Ct. at 2349-59 (Brennan, J., dissenting). 
more expansive than, Scalia's understanding. The existence of a specific, firmly entrenched societal tradition, Brennan argued, cannot be the necessary condition for the existence of a liberty protected against state action. To do so would be to render the clause a "redundancy": any liberty specifically enshrined in tradition will not be undercut by state law. ${ }^{12}$ The existence of a "tradition" is indeed relevant to the existence of a "liberty" protected against societal overreach, Brennan conceded, but the tradition must be understood generally, not specifically. ${ }^{13}$ Furthermore, and perhaps more importantly, the source of the tradition is not "society," but Supreme Court precedent. The liberties protected by due process are those general traditions that the Court has identified precedentially: parenthood, intimacy, reproduction, contraception, sexuality, and the like. ${ }^{14}$ Thus, under Brennan's approach, there is indeed a tradition protecting the sort of liberty Michael $H$. was seeking to enforce: "we," meaning the liberal Warren-Burger Court, have "traditionally" upheld the rights of unwed fathers to maintain relationships with their children. ${ }^{15}$ That tradition is not negatived, but violated, by a state statute that refuses to protect such rights where the child's mother is married to another man. ${ }^{16}$

Similarly, under Brennan's approach, the major cases of the modern substantive due process revival were also correctly decided. Thus, "we"-meaning the remaining members of the Warren-Burger Court-have traditionally protected the liberty and freedom of persons seeking medical procedures and making decisions about when to start or expand families. Accordingly, that tradition is not negatived, but instead violated, by state statutes criminalizing abortion, and hence those statutes are unconstitutional, and Roe $v$. Wade $^{17}$ was decided correctly. Likewise, "we"-the relevant members of the Court-have "traditionally" protected the "right to be left alone," and again, that tradition is violated, not negatived, by the existence of statutes criminalizing consensual sodomy. Therefore, Bowers v. Hardwick ${ }^{18}$ was decided erroneously. To take a final example, "we"-again the liberal members of the Court-have "tradi-

\footnotetext{
12 See id. at 2351.

${ }^{13}$ See id. at 2350.

14 See id.

${ }^{15}$ See id. at 2351-55.

${ }^{16}$ See id. at 2355.

${ }^{17} 410$ U.S. 113 (1973).

18478 U.S. 186 (1986).
} 
tionally" protected the right to bodily control and the right to decide one's own medical fate; this tradition is violated, not negatived, by the existence of statutes qualifying the "right to die" with weighty evidentiary presumptions. Therefore, the Court was right in Cruzan v. Director, Missouri Department of Health ${ }^{19}$ to articulate a basic right to die, ${ }^{20}$ and indeed the Court should have gone further than it was willing to go in giving substance to that right. Thus, the use of general rather than specific traditions, grounded not in societal custom, but in the Warren and Burger Courts' decisions that protected liberty, gives the formulation considerably more breadth than Scalia's explicitly narrow and conservative formulation.

In spite of the manifest differences between Justice Scalia's and Justice Brennan's accounts, however, and the sharply differing results to which those approaches lead, both positions-not just Scalia's-are deeply conservative understandings of the due process clause, for three reasons. First, and most obviously, both positions define the liberty protected by the due process clause by reference to some set of past historical traditions. The traditions on which they depend are different: Scalia prefers to defer to societal or communitarian tradition, whereas Brennan wants to rely on the traditions identified in the judicial precedent from a particular era. Both, nevertheless, define liberty in terms of past tradition rather than, for example, by reference to some understanding of the ideally free or autonomous individualist life.

Second, Justice Brennan, no less than Justice Scalia, understands the due process clause as a means by which we can "conserve" some aspect of the past against the encroachments of contemporaneous or future majoritarian or judicial power. Justice Scalia seeks to protect, or conserve, the traditions, and particularly the moral traditions, of the community against ill-advised, precipitous state actions. Brennan, by contrast, seeks to protect, or conserve, the traditions respected by a particular set of Supreme Court precedents, as well as, perhaps, the "tradition" of precedent itself, against future and contemporaneous Court betrayals of their underlying principles. But both view liberty, and the due process clause that protects it, as means of protecting not so much individual liberty for its own sake, but individual liberty to participate in past traditions

19110 S. Ct. 2841 (1990).

${ }^{20}$ See id. at 2864 (Brennan, J., dissenting). 
that are worthy of protection. To put the same point somewhat differently, both are "backward looking" understandings of liberty and of due process: they both define liberty by looking not at what liberty is, as understood by liberal philosophical exegesis, political oratory, or even linguistic analysis, but rather by examination of what it has meant according to the traditions or customs of the past.

Lastly, both Justices' approaches, Brennan's no less than Scalia's, represent "communitarian" rather than "individualistic" understandings of the meaning of liberty. Neither Justice asks what the ideally autonomous or liberated individual life demands or requires of the state. Rather, both understand "liberty" as meaning essentially the liberty to conform to traditions, though traditions variously and differently understood. What is thus protected, at most, is the liberty to obey or conform to the dictates of relevant traditions, rather than the liberty to rebel against them, in the face of state or majoritarian action seeking to deny that liberty. For this reason as well, it is fair to characterize not only Scalia's approach, but Brennan's as well, as conservative. In summary, both Justices seek to protect and conserve the traditions of the past against contemporaneous or future change, both are backward looking in their temporal orientation, and both are on their own terms antiindividualist. They protect not the individual's right to be different, idiosyncratic, iconoclastic, or rebellious, but rather the individual's right to conform to tradition and obey its dictates.

Furthermore, the conservatism of Brennan's discussion of liberty in Michael $H$. is not simply a peculiarity of that case. Rather, it reflects the general tenor and much of the language of the liberal Justices' understanding of substantive due process that has evolved over the last twenty years. Indeed, virtually all of the recent substantive due process cases hailed as great liberal victories-Roe $\boldsymbol{v}$. Wade, Griswold v. Connecticut, ${ }^{21}$ Eisenstadt v. Baird, ${ }^{22}$ and the recent Cruzan decision-are "conservative" in precisely the same sense as is Brennan's opinion in Michael $H$. All of these cases define liberty by reference to traditions which are themselves identified by reference to the past; they are all "backward looking" rather than forward looking in their orientation; and they all ultimately protect the "liberty" of the individual to conform to established historical traditions, rather than the liberty of the individual to rebel against

21381 U.S. 479 (1965).

22405 U.S. 438 (1972). 
them. Thus, the liberty protected in Roe, Griswold, and Eisenstadt, quite generally, is the "liberty" to participate in the traditionally protected familial and marital decisions regarding reproduction and is defended precisely on those grounds. ${ }^{23}$ Similarly, the "liberty" defended in Cruzan is the liberty to participate in the traditionally protected realm of decisions regarding one's own medical treatment. ${ }^{24}$ Likewise, the dissenters in Bowers rested their defense of sexual liberty not on the value of sexual liberty per se, but on the traditionally protected "right to be left alone." 25

Why is this? Why is it that the interpretation of liberty offered by the liberal wing of the Court, not only in Brennan's expansive discussion of the issue in Michael $H$., but also in the major modern substantive due process cases generally, differs only marginally from that offered by the conservative wing? The substantive due process doctrine is surely susceptible to more interpretations than the conservative interpretation it has received over the bulk of this century. More importantly, the ideal of liberty is surely susceptible to more and more progressive interpretations than either the traditionalist or precedential accounts given by Scalia and Brennan respectively. Specifically, there are at least two understandings of "liberty" that differ dramatically from both Scalia's and Brennan's accounts. Both of these understandings undoubtedly have played a role in our political debates, political history, and political dreams. Both could also-although to date they have not-played a role in constitutional interpretation as well.

First, as liberal philosophers from John Locke ${ }^{26}$ to John Rawls ${ }^{27}$ have argued, the content and meaning of "liberty" might be properly derived not from historical tradition-whether communitarian or precedential-but from an ideal conception of an autonomous life. The content of that ideal is of course controversial, but that does not mean that it is not ascertainable. A life may not be ideally "autonomous," for example, without a guarantee of

23 See Roe, 410 U.S. at 152-56; Eisenstadt, 405 U.S. at 453-55; Griswold, 381 U.S. at 485-86.

24 See 110 S. Ct. at 2851-52.

25478 U.S. 186, 199-214 (1986) (Blackmun, J., dissenting).

26 See J. LOCKE, Two TREATISES OF GOVERNMENT 132 (T. Cook ed. 1947) ("The natural liberty of man is to be free from any superior power on earth, and not to be under the will or legislative authority of man. . . . The liberty of man in society is to be under no other legislative power but that established by consent in the commonwealth.").

27 See J. RAWLS, A TheORY Of JUSTICE 202 (1971). 
employment, minimal sustenance, and shelter, as John Dewey argued, ${ }^{28}$ or without a just distribution of resources, as Rawls has argued. $^{29}$ Likewise, a life may lack autonomy without some sphere of privacy in which to conduct intimate affairs, without rights and freedoms retained from the state of nature, or without some amount of education. Whatever the merits of these arguments, they share one feature: they derive the content of liberty not from historical tradition, but from liberal ideals. Their validity depends not on the presence or absence of "traditions" guaranteeing welfare rights, privacy rights, education, or natural rights, but on the ascertainable conditions of a truly autonomous life.

A second possible understanding of liberty comes not from liberal philosophy but from radical politics and practice. "Liberty" might be understood in a "liberationist," rather than a "libertarian" sense. On this account, liberty requires liberation from any number of pernicious constraints, whether imposed by the state, private persons, or nature. This may include liberation from hunger, from slavery, from poverty, from sexual abuse, from "the patriarchy," and from racism itself. "Liberty," on this view, requires liberty from bondage, whether that bondage be the result of state oppression, state meddling, or private action.

Somewhat paradoxically, this "radical" interpretation of liberty has the virtue of being at least somewhat reflective of the history of the due process clause that protects it. The fourteenth amendment's due process clause might have meant originally that no one's "liberty" may be taken by anyone, such as a slaveowner, other than the state (and then only with due process). What due process requires, in other words, is that the state and only the state may be "sovereign" over the individual and her liberty. Correlatively, the due process clause imposes on the state an obligation to prohibit the "private sovereignty" effected by private relationships of domination and subordination, such as that of enslavement. By extension, then, in modern times the state may also have an obligation, on this view of both "liberty" and "due process," to prohibit the private sovereignties created by unchecked racism, sexual violence, or homophobic violence as well. If the state fails to

${ }^{28}$ See J. DEWEY, LIBERALISM AND SOCIAL ACTION 31 (Capricorn ed. 1963). See also J. DEWEY, INDIVIDUALISM OLD AND NEW 89 (1930).

${ }^{29}$ See J. RAWLS, supra note 27, at 204-05 (arguing that worth of liberty is adversely affected by poverty, ignorance, or "lack of means generally"). 
do so, it has deprived the individual of her liberty, without due process.

Why, then, does "liberty" receive from even the liberal members of the Court at best a broad interpretation and a defense grounded in the conservative values of fidelity to the past, conformity to traditions, the primacy of the community over the individual, and respect for judicial precedent, rather than liberal commitments to autonomy or radical commitments to liberation? The easiest, but ultimately least satisfying explanation is that it is simply politics: it may be that appearances notwithstanding, Justice Brennan and the other liberals on the Court are in fact only marginally more liberal than Justice Scalia and his fellow conservatives. If so, the similarities between the two approaches might stem from their shared conservative roots, just as their manifest differences might stem from their obvious, but in the end superficial, political differences. ${ }^{30}$ There are, though, serious problems with this explanation. First, appearances are dramatically to the contrary; Justice Brennan is a modern liberal jurist if anyone is. Second, and perhaps more importantly, neither Justice Brennan nor Justice Scalia, in Michael $H$. or elsewhere, write as if politics alone dictated their different legal conclusions. Rather, both write as though their understanding of "the Law," and their understanding of the appropriate scope of the judicial role, led them to their divergent formulations. It may be worthwhile exploring other possible explanations which would take seriously both their clear political differences as well as their clearly stated legal and jurisprudential aspirations.

One possible alternative explanation, put forward with tremendous force by Cass Sunstein in a series of articles on the due process clause of the fourteenth amendment, is that the clause itself is generally "backward looking" in its orientation and that it has been from its inception. ${ }^{31}$ In sharp contrast to the equal protection clause-which is at least potentially progressive and "forward looking" -the history of both the fifth and fourteenth amendments' due process clauses fairly clearly direct the Court to traditional, historical sources for ascertainment of the content of the liberty

30 Cf. Grey, Eros, Civilization, and the Burger Court, 43 LAW \& CONTEMP. PROBS. $83(1980)$ (arguing that need for social order, not respect for liberty, lies behind the liberal Justices' willingness to grant constitutional protection to sexual freedom).

31 See Sunstein, Lochner's Legacy, 87 Colum. L. REv. 873, 912-17 (1987) [hereinafter Sunstein, Lochner's Legacy]; Sunstein, Sexual Orientation and the Constitution: A Note on the Relationship Between Due Process and Equal Protection, 55 U. CHI. L. REV. 1161, 1170-78 (1988) [hereinafter Sunstein, Sexual Orientation]. 
they protect. ${ }^{32}$ The equal protection clause is the source of, and tool for, idealistic, progressive challenge to the status quo. In contrast, the due process clause, like the takings and contracts clauses, historically has been the tool of the conservative impulse to preserve the liberties defined by the past and to protect against overzealous, imprudent change.

It is no coincidence, following Sunstein's logic, that the Court in Lochner $v$. New York ${ }^{33}$ understood the liberty protected by the due process clause as consisting of the liberty to enter contracts on individually chosen terms, thereby preserving the status quo, free from the redistributive and paternalist influences of reformist workplace legislation. The broad mistake of the Lochner Court, then, was to embrace a view of the entire Constitution as essentially analogous to this conservative understanding of the due process clause. The narrow mistake of the Court in Lochner itself, however, simply for purposes of its due process jurisprudence, was not that it understood due process conservatively, but that it viewed it as yet another substantive limit on state action. ${ }^{34}$

${ }^{32}$ See Sunstein, Lochner's Legacy, supra note 31, at 884-86; Sunstein, Sexual Orientation, supra note 31 , at $1170-78$.

${ }^{33} 198$ U.S. 45 (1905).

${ }^{34}$ Sunstein does not make this argument in any one place, but I would reconstruct it from his suggestions in Sexual Orientation, supra note 32, and Lochner's Legacy, supra note 32, as follows. The "liberty" that the individual possesses, and that is protected by the fourteenth amendment, tends to be understood as incorporating a "baseline" of common law origins. This, in turn, has the effect of constitutionally protecting the given distribution of wealth and privilege against legislative change. Generally, this reliance on unexamined baselines is misplaced. Overreliance on improper "baselines" for constitutional decision-making, Sunstein would argue, haunts not only due process interpretation, but several areas of constitutional law. Because of this recurrent reliance on common law baselines, a legislature that upsets the entitlements provided by the common law is viewed as having "acted," acted "affirmatively," and acted affirmatively in a way which upsets pre-legal individual liberties. On the other hand, a legislature that leaves those entitlements intact has not acted, but it has respected liberty. Similarly, a law which redistributes such entitlements is regarded as "redistributive," and hence a violation of liberty, of the takings clause, and possibly of the contracts clause. For these reasons, such a law is acting outside the scope of police power, whereas a law that leaves those entitlements intact is regarded as having respected liberty. A law which upsets these "natural" entitlements is regarded as impermissibly biased, and a law that leaves them intact is regarded as "neutral." This was also the underlying rationale of the major substantive due process cases from the Lochner era.

The repudiation of Lochner, Sunstein argues, should be understood as a repudiation of precisely this understanding of the exalted constitutional status of common law entitlements, rather than a repudiation of judicial activism or an affirmation of legislative supremacy. Common law entitlements may or may not be entitled to constitutional protection; whether they are depends on the clause and the 
How, on this view, does one account for the recent "substantive due process" decisions that appear to be liberal victories, such as Roe or, arguably, Griswold? Although Sunstein has not addressed the question directly, he has indirectly. According to Sunstein, among others, the statutes involved in these cases, although determined to be violations of the due process clause, properly should be understood as violations of the equal protection clause instead. ${ }^{35}$ What is at stake in Roe, for example, is not "privacy" or "liberty," but the subordination of women as a class through the imposition of laws that have the effect of "turning women's reproductive capacities into something for the use and control of others." 36 And, the equal protection clause easily can be understood as a constitutional mandate to the states to avoid or to correct for precisely this kind of subordination. Furthermore, that kind of subordination rests on precisely the same conservative impulse as the Lochner decision itself. Whereas the Lochner Court treated the common law as providing the baseline against which intrusions upon liberty are determined, the impulse to criminalize abortions treats "nature" as

context. In some spheres of constitutional decision-making, this reliance on the common law as the baseline of constitutionally protected interests is entirely properthe contracts clause and the takings clause are two examples. But in a large number of other contexts it is entirely inappropriate. It is inappropriate, for example, for us to judge whether or not the state action requirement has been met by appeals to hidden "baselines" of common law entitlements, such that if those baselines have been violated, the state has acted, but if they have been maintained, there is no state action. The repudiation of Lochner is a repudiation of this view that the existing distribution of entitlements and wealth is a function of "nature" and hence an aspect of our natural liberty. That distribution is a function, generally, of the common lawvery much a state, and governmental, creation.

Although Sunstein himself is not tremendously clear on the point, his understanding of the repudiation of Lochner seems to teach this lesson regarding substantive due process itself. To the considerable degree that the substantive due process doctrine is dependent upon this conception of the common law as the "baseline" for determining infringements on personal liberty, the doctrine in its entirety-rather than just one possible interpretation of it, and certainly rather than judicial activism per se-should be understood as undermined by the repudiation of Lochner. Like the takings clause and the contracts clause, liberty under the due process clause during the Lochner era was understood by reference to hidden common law baselines establishing entitlements. But unlike the contracts or takings clause, the "substantive due process" doctrine is, in its entirety, a mistake; furthermore, it is a clearly "repudiated" one. If substantive due process must mean what it meant to the Lochner Court-that state redistribution of existing entitlements violates liberty-then it should be abandoned, for that was the central message of Lochner's repudiation.

${ }^{35}$ See C. Sunstein, Neutrality in Constitutional Law, With Special Reference to Abortion, Surrogacy, and Pornography (unpublished manuscript on file with author).

${ }^{36} I d$, at 43. 
providing such baselines. Therefore, the repudiation of Lochner, far from undercutting the outcome in Roe, as argued by scores of the case's critics, in fact mandates it, but for reasons utterly inconsistent with those espoused in the decision itself. The repudiation of Lochner, and of the substantive understanding of the due process clause upon which it depends, far from implying that Roe is wrongly decided, implies a repudiation of the use of the very sorts of "baselines" which underlie the criminalization of abortion and, hence, the subordination of women. The repudiation of Lochner and of substantive due process, then, requires a reading of equal protection-not of due process-that in turn justifies the outcome in Roe.

The understanding of the fourteenth amendment that emerges from this Sunsteinian view of due process and equal protection is both neat and neatly schizophrenic: the equal protection clause is "forward looking" while the due process clause is "backward looking"; the equal protection clause uses ideals of equality and non-subordination as a "baseline," while the due process clause uses extant practices and distributions; the equal protection clause, in essence, is progressive, whille the due process clause is conservative. The equal protection clause, then, protects against the very sorts of "subordination" that the due process clause, under a substantive interpretation, requires. If so, then the conservatism of interpretations of substantive due process, even by the liberals on the Court, is not so mysterious. It simply reflects the historic conservatism of the due process clause itself, and of the liberty it purports to protect.

One further and closely related explanation of the conservatism of due process adjudication has been suggested-more indirectly than directly-by other progressive scholars of the due process clause. ${ }^{37}$ The conservatism of the interpretations of due process rendered by even liberal Justices may be a function not so much of the historical conservatism of the clause itself, but of the political and moral conservatism of the ideal of liberty it is designed to protect. From this perspective, liberty, not the due process clause, accounts for the conservative tilt of the substantive due process cases; individual liberty simply is a conservative ideal, and it is

${ }^{37}$ See C. MACKINNON, FEMINISM UNMODIFIED 164-66 (1987) [hereinafter C. MACRINNON, FEMINISM UNMODIFIED]; C. MACKINNON, TOWARD A FEMINIST THEORY OF THE STATE 159-70 (1989) [hereinafter C. MACKINNON, TOWARD A FEMINIST THEORY]. 
therefore not surprising that even liberal interpretations of its content reflect that fact. Promotion of individualist values and individual freedom "frees up" private action that will inevitably entail the subordination of weaker parties, whether the particular "liberty" is physical, economic, sexual, or ideational. ${ }^{38}$ To be free of state control means, in essence, to be free to subordinate otherswhether through one's superior economic strength manifested in self-serving and exploitative contracts, superior physical force facilitating physical or sexual oppression, or superior intellectual clout and access facilitating cultural tyranny.

Implicit in this view is an unavoidable "trade-off" between individual liberty and egalitarian ideals; protecting freedom or liberty inevitably entails the reinforcement of hierarchy. Protecting the individual's liberty to set contract terms further entrenches economic hierarchy. Protecting the individual's liberty to utter racially defamatory slurs further entrenches racial hierarchies. Protecting the individual's liberty to do as he wishes within the "privacy" of his own home, marriage, or family, perpetuates the subordination of the women and children over which, as a consequence of his protected liberty, he enjoys dominion. Individual liberty necessarily implies the liberty to engage in private acts of subordination. As we increase liberty, we threaten equality, and we can only promote meaningful equality by curtailing, to some extent, the individual liberty with which it is inevitably at war.

There is a great deal to be said for both of these explanations. Both Sunstein's analysis of due process and the related critique of liberty have the virtue of taking the due process liberty cases "at face value." The reason for their conservative tilt, on both accounts, stems from the content of the law itself, not from deep unobservable psychological facts or impermissible political motivations. Both explanations respect the boundaries, so to speak, of legal discourse. They also both have the virtue of explaining not only the major conservative due process decision of the century-Lochner-but also the more subtle conservatism behind the Court's "liberal" modern due process cases, from Griswold to Roe. There may also be historical support for both positions. The progressive account of liberty summarized above, for example, is echoed not only in modern libertarian dogma, but also in the account of liberty

${ }^{38}$ See C. MACKInNoN, FEMINISM UNMOdIFIEd, supra note 37, at 164-66; C. MACKINNON, TOWARD A FEMINIST THEORY, supra note 37, at 163-70. 
espoused in The Federalist. ${ }^{39}$ And, as Sunstein has suggested, at least some of the framers of the fifth amendment may indeed have viewed the due process clause as an intrinsically conservative doctrine, directing the focus of inquiry "backward" to the demands of an established natural law tradition, rather than forward to the demands of only vaguely conceived utopian ideals. ${ }^{40}$

Both accounts, however, have real problems. First, the Sunsteinian claim that substantive due process is a conservative doctrine and equal protection is progressive, even if historically supportable, seems normatively and even linguistically indefensible. It is not at all obvious that the guarantee that liberty will not be taken without due process is intrinsically more conservative than the guarantee that the state will provide equal protection of the laws. Nor is it at all obvious that liberty itself, as a political ideal, is intrinsically more conservative than the ideal of equality. As shown above, the ideal of liberty as a restraint on state action can certainly be understood in a liberal or radical sense, as well as in a conservative one. Purely as a matter of political theory, to say nothing of political morality, both positions are unappealing: they read into the fourteenth amendment a peculiarly schizophrenic attitude toward social change.

Second, whatever may have been the original intent of the framers of the fifth amendment's liberty clause, the history as well as the judicial interpretation of the fourteenth amendment cut against Sunstein's claim that the equal protection clause and the due process clause point in opposite political directions. Although the equal protection clause is surely susceptible to progressive interpretations, with only occasional exceptions, ${ }^{41}$ it has been interpreted by the Court for the most part narrowly and formally and with profoundly conservative consequences. ${ }^{42}$ Just as "liberty" has received a predominantly conservative and traditionalist gloss, so

${ }^{39}$ See THE FEDERALIST No. 10 (J. Madison).

${ }^{40}$ See Sunstein, Sexual Orientation, supra note 31, at 1171.

41 The most notable exception, of course, is Brown v. Board of Educ., 349 U.S. 294 (1954).

42 See, e.g., City of Richmond v. Croson, 109 S. Ct. 706 (1989) (increasing evidentiary burden on minorities to show violation of the fourteenth amendment's equal protection clause by requiring specific proof of past discrimination); University of California v. Bakke, 438 U.S. 265 (1978) (restricting affirmative action by limiting consideration of race in admissions decisions); Washington v. Davis, 426 U.S. 229 (1976) (reducing evidence available to minorities sufficient to prove discrimination by finding that disproportionate effects alone do not warrant conclusion of purposeful discrimination). 
equal protection has typically been interpreted as requiring a formal rather than substantive equality that has itself become an obstacle of, rather than a vehicle for, progressive movements toward racial or sexual justice. Sunstein sees, or perhaps wants to see, in the fourteenth amendment a "division of labor": due process and liberty as a vehicle for conserving the past against precipitous change, and equal protection as a vehicle for progressive challenges to the status quo. Whatever may have been the case at the amendment's inception, this theory has not been borne out by subsequent judicial implementation.

More to the point, from a progressive perspective, both of these arguments seem unwise. They concede far too much, and for no obvious reason. Even if it is true that the major judicial interpretations of substantive due process during the course of this century have been overwhelmingly conservative, it may not be because of the inherent conservatism of either the constitutional mandate of due process or the moral or political ideal of "liberty." If not, then progressives give away too much by conceding interpretive power over the moral and constitutional ideal embedded in the due process clause and the liberty it protects to conservative rhetoric and ideology. For surely either the liberal, autonomy-promoting understanding of liberty or the radical liberationist conception could have informed the Court's substantive due process analysis of the last twenty years. It seems fair to say, though, that neither has, at least not in any clear or sustained fashion.

To take just one example, the "liberty" protected by the reproductive "rights" enunciated in Roe can be understood in either of the two senses sketched above. Reproductive choice may be essential for an autonomous life, and "liberation from" the spectre of unwanted pregnancy, childbirth, and motherhood may be an accurate understanding politically of what the "pro-choice" political and liberationist movement is all about. It is not necessary, in other words, to reconceive the progressive substantive due process decisions as "equal protection" cases in disguise, in order to reach the same outcome while avoiding libertarian or traditionalist understandings of the liberty which due process protects. The ideal of liberty is susceptible to multiple interpretations. Rather than reconceptualize progressive liberty cases as true equality cases-on the premise that either liberty, due process, or both are intrinsically conservative, and hence in a deep sense inconsistent with progressive outcomes-we might more profitably reconceptualize the ideal of liberty itself. 
One alternative explanation of the conservatism which inheres in the purportedly liberal interpretation of the liberty protected by the due process clause is that Justice Brennan and the other liberals on the Court, no less and no more than Justice Scalia, try in their judging to be true to ideals of "good" judging. They therefore interpret the due process clause in such a way as to promote, or to be true to, a range of "adjudicative virtues." And it is those virtuesnot the constitutional ideal of "liberty"-that are themselves inherently conservative. It is good judicial decision-making, rather than any part of the Constitution, that is (and should be) sensitive to historical tradition, custom, and precedents; that is "backward looking" rather than "forward looking" in its aspiration to cohere with past patterns of law; and that is communitarian rather than individualist in its respect for the mandates of "ordered liberty." If that is right, then it would not be surprising that even comparatively "liberal" interpretations of constitutional phrases, which are themselves a part of adjudicative discourse and which accordingly aim for adjudicative virtue, will not be as liberal as liberal interpretations of the same phrase found in other discursive contexts.

Indeed, if we take Justice Brennan's decisions at face value, it seems fair to say that his broad precedential approach to liberty, no less than Justice Scalia's narrowly traditionalist account, is heavily and explicitly constrained by his sense of the requirements of an ideal of good-meaning moral-judicial decision-making. The difference, then, between Brennan and Scalia's approaches is a function not (only) of simple politics, but of the differences between the particular conception of the ideal judicial decision and, hence, the particular adjudicative virtue harbored by each Justice. Thus, Scalia's narrow understanding of liberty and the due process that protects it is an explicit attempt to minimize the potential for arbitrary judicial decision-making that runs counter to the dictates of democratic desire. Insistence on narrow rather than broad understandings of the general clauses of the Constitution, in Scalia's mind, is the surest way to protect against not only arbitrary or whimsical decisions, but also against the judicial tyranny of judges acting as super-legislators in pursuit of their own political values rather than justice. Brennian's comparatively liberal or broader understanding of "tradition" is unquestionably driven in part by a very different political morality, but the conservatism of his approach, compared with non-judicial liberal interpretations, may best be explained by its jurisprudential motivation. Brennan's reliance on precedentially identified traditions to fill in the content of "liberty" 
can perhaps best be understood as an attempt to protect the "integrity" and "consistency" of the considerably more liberal body of case law in which the Warren and Burger Courts broadly construed the clause in question. Integrity and consistency, no less than the avoidance of arbitrary, whimsical or tyrannical decisions, are obviously adjudicative virtues. And like those virtues, they are themselves "conservative"; they counsel for decisions that cohere with patterns of principles that speak to us from the past.

If this is all or even part of the story, then the conservatism of the due process clause derives at least in part from the fact that the Constitution receives its meaning almost entirely from judges acting under the intrinsically conservative duties imposed upon them by virtue of their judicial role, and it is not a function of the inherent or historical association of the clause with conservative political ideals. This hypothesis-that the conservatism of even the liberal Justices' liberty jurisprudence is in part a function of ethical constraints regarding the nature of moral judicial decisionmakingexplains at least one puzzle: it is for this reason that judicial understandings of liberty authored by the liberal judges are so much more conservative than interpretations of "liberty" suggested by liberal political theorists or liberal political activists. For indeed, it seems to be only judges who are wedded to the peculiar idea that the content of liberty should be and has been derived from past communitarian or precedential traditions. As discussed above, liberal political philosophers and political activists think of liberty in any number of ways, ${ }^{43}$ but virtually none of them harken back to tradition, either the conservative traditions of a society or the traditions identified as essential to liberty by a liberal Supreme Court. If the conservatism of due process interpretation is due to a quest for adjudicative virtues which are themselves conservative, then it is not surprising that judicial interpretations of liberty are so much more conservative than political interpretations of the same ideal in non-legal discourses. If judges are heavily influenced by ethical imperatives of decision-making that are peculiar to adjudication, then it is not surprising that they have developed a set of definitions of "liberty" that also seem peculiar to adjudication. Those definitions owe as much to the ethical demands placed upon judges as they do to the text of the Constitution, its history, or the political will of its interpreters.

${ }^{43}$ See supra notes $26-29$ and accompanying text. 
What this implies is simply that if we follow the suggestion of the growing number of commentators-neo-civic-republican and otherwise-arguing for an end to the monopolization by the Court of constitutional interpretation, then we should expect to see a far wider range of interpretations of the "liberty" which the state must respect, nurture, or "leave alone" than that represented by the Scalia-Brennan poles of debate in Michael H. v. Gerald D. Freed of the constraints of the panoply of demands imposed by the adjudicative virtues-the various needs to write narrow decisions, to respect the rights of similarly situated persons, to adhere to the patterns established by past decisions-constitutional interpreters, whether citizens, legislators, or commentators, may see any number of potential meanings in the due process clause to which the Court, by virtue of its identity as a court, is blind. It may be, for example, that liberty is impossible in the face of chronic homelessness, joblessness, or hunger and that this fact should operate as a constitutional constraint on what the state may refuse to do, as well as what the state may do. It may also be that liberty is impossible in the face of stultifying, demoralizing, constant, private oppression and that this fact as well should constrain constitutionally what the state may neglect as well as what it may do. The due process clause may grant us, in other words, both "affirmative" liberty rights and rights to be free of private oppression. Non-judicial constitutional interpreters, freed of the constraints of judicial ethics, may find these arguments more persuasive than virtually any court would, not only as the conservative Rehnquist Court would.

The modern Court, of course, has held to the contrary: it has ruled consistently that liberty does not embrace affirmative welfare rights and that the fourteenth amendment does not reach private action. Whether they were right or wrong in doing so is not the argument of this paper. All I want to suggest is that they have reached these conservative interpretations in large part because they are a court. Should other interpreters enter the debate-should Congress, for example, accept its section five burden of passing legislation for the purpose of enforcing the liberty guarantee of the fourteenth amendment-they may see very different and much broader meanings in the general phrases of the amendment than the Court has seen to date. Congress is not burdened by the ethical imperative to write decisions that are consistent with decisions that have gone before. It is not burdened with the need to treat like cases alike. Nor is it charged with the task of "conserving" the societal traditions of the past. It has no reason to interpret liberty 
in such a way as to maintain a "seamless web" of precedent. It is charged with the task of enforcing the mandate of the fourteenth amendment, and it is generally charged with the work of distributing resources in a just manner. It is not asking too much, then, to expect Congress to do its distributive and redistributive work in a way which promotes rather than impedes or frustrates true individual "liberty"-understood not as societal tradition and not as judicial precedent, but as the necessary societal conditions for a genuinely free, autonomous life. 